\title{
Barnyardgrass control using tank-mixed herbicides with saflufenacil and its influence in photosynthesis and chlorophyll fluorescence
}

\author{
Cassiano Salin Pigatto ${ }^{1 *}$ (D) Camila Peligrinotti Tarouco $^{2}$ (D) Fernando Teixeira Nicoloso $^{2}$ (D) \\ Álvaro Luis Pasquetti Berghetti ${ }^{2}$ (i) Glauco Pacheco Leães ${ }^{1}\left([)\right.$ Isabel Schlegel Werle ${ }^{1}(\mathbb{C})$ \\ André da Rosa Ulguim ${ }^{1}$ (D)
}

${ }^{1}$ Departamento de Defesa Fitossanitária, Centro de Ciências Rurais (CCR), Universidade Federal de Santa Maria (UFSM), 97105-900, Santa Maria, RS, Brasil. E-mail: cassianosalinp@gmail.com. "Corresponding author.

${ }^{2}$ Departamento de Biologia, Universidade Federal de Santa Maria (UFSM), Santa Maria, RS, Brasil.

ABSTRACT: The objectives of this research were to evaluate the interaction between herbicides mixed with saflufenacil for the control of barnyardgrass and to determine the effect on photosynthetic and chlorophyll fluorescence parameters. The experiment was conducted in a greenhouse in a $2 x 8$ factorial scheme, whose factor A tested resistant and susceptible biotypes; and factor B the herbicides: saflufenacil (70 $g$ a.i. $\left.\mathrm{ha}^{-1}\right)$, clomazone $\left(180 \mathrm{~g}\right.$ a.i. ha- $\left.{ }^{-1}\right)$, imazapyr + imazapic $\left(73.5+24.5 \mathrm{~g}\right.$ a.i. ha $\left.\mathrm{a}^{-1}\right)$, and cyhalofop $\left(360 \mathrm{~g}\right.$ a.i. ha $\left.\mathrm{a}^{-1}\right)$, the mixtures of these herbicides with saflufenacil, and control without treatment. Weed control was assessed 7, 14, 21 and 28 days after herbicide application (DAA), as well as shoot dry matter at 28 DAA, photosynthetic parameters using infrared gas analyzer (IRGA), and emission of chlorophyll a fluorescence after 24 and 28 hours of application of treatments, respectively, and interaction of herbicides. Combination of saflufenacil with the herbicides tested in general did not change the response of both barnyardgrass biotypes to the herbicides used. The resistant biotype showed a lower negative effect on chlorophyll fluorescence and photosynthesis parameters in the combination of herbicides with saflufenacil. The herbicide cyhalofop was effective for the control of ALS-susceptible and resistant barnyardgrass.

Key words: Echinochloa spp., herbicide mixture, fluorometer, genetic variability.

Controle de capim-arroz mediante associações de herbicidas com saflufenacil

e influência na fotossíntese e fluorescência de clorofila

RESUMO: $O$ objetivo deste trabalho foi avaliar a interação entre herbicidas associados ao saflufenacil para o controle de capim-arroz e a determinação do efeito dos herbicidas sobre os parâmetros fotossintéticos e de fluorescência de clorofila. O experimento foi conduzido em casa de vegetação em esquema fatorial $2 x 8$, cujo fator A testou os biótipos resistente e suscetivel; e o fator $B$ os herbicidas: saflufenacil (70 $\mathrm{g}$ i.a. ha ${ }^{-1}$ ),

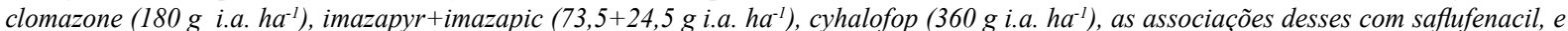
testemunha sem tratamento. Foi avaliado o controle aos 7, 14, 21 e 28 dias após a aplicação dos herbicidas (DAA), massa seca da parte aérea aos $28 \mathrm{DAA}$, avaliação de parâmetros fotossintéticos com analisador de gás infravermelho (IRGA) e emissão de fluorescência da clorofila a 24 e 48 horas após aplicação dos tratamentos, respectivamente, e interação dos herbicidas. A associação de saflufenacil com herbicidas testados na maior parte não modificou a resposta dos herbicidas para o controle de capim-arroz em ambos os biótipos. O biótipo resistente apresentou menor efeito negativo nos processos de fluorescência de clorofila e parâmetros de fotossíntese na associação de herbicidas com saflufenacil. O herbicida cyhalofop associado ao saflufenacil demonstra ser eficiente para o controle de capim-arroz suscetivel e resistente a ALS.

Palavras-chave: Echinochloa spp., mistura de herbicidas, fluorômetro, variabilidade genética.

\section{INTRODUCTION}

Brazil has succeeded in raising agricultural productivity of flooded rice (Oryza sativa) due to new technologies, such as the Clearfield $^{\circledR}$ (CL) system, which facilitated the control of major weeds such as weedy rice (Oryza sativa) and barnyardgrass (Echinochloa spp.) (CONAB, 2019). The CL system has rice genotypes that are tolerant to the imidazolinones (IMI) chemical group, and has become the major form of weed control in rice Brazilian fields. However, exclusive and improper use 
of this technology and other chemical control options with poor utilization of non-chemical practices, have selected weed resistance to herbicides (HEAP, 2019), among them, barnyardgrass.

Barnyardgrass has high competition ability for limiting resources such as light, water and nutrients, is reproduced by seeds, has annual cycle, rapid germination and emergence, high adaptability to the crop ecosystem and to the C4-type photosynthesis cycle (KISSMANN et al., 2007). Thus, competition for light and $\mathrm{CO}_{2}$ is of great importance because this interferes with the rate of photosynthesis and the physiological activity of roots, with direct effect on biomass accumulation and crop yield (ZHANG et al., 2017). Another factor that enhanced competition is the physiological and morphological similarity of plants of the same family, as sunlight since solar irradiation and other demands for resources are often similar (GALON et al., 2018). Thus, yield losses are related to presence of resistant barnyardgrass biotypes on rice fields and to avoid it, the farmers are using tank-mix to their control.

Tank-mixed herbicides having different mechanisms of action are a viable alternative for application on lands where there is a great number of weeds with different grass and broadleaf species, as it allows broadening the action spectrum and helps the control of resistant species (JHALA et al., 2013). Saflufenacil is an herbicide that inhibits the protoporphyrinogen IX oxidase (PROTOX) enzyme and acts on the route of chlorophyll synthesis (COSTA et al., 2017). This herbicide is an option for use in combination with other herbicides, being an alternative for the control of broadleaf weeds (GROSSMANN et al., 2011); and although, is considered selective Poaceae Family, a high phytotoxicity effect is observed when applied. Thus, saflufenacil can be an alternative for the control of resistant weed species existing in rice fields, especially when combined with other herbicides.

Knowledge on the interactions between herbicides is of great importance to understand the response to the products mixture, which can be synergistic, antagonistic or additive (COLBY et al., 1967), and there are few studies in the literature on the effect of using saflufenacil alone or in combination with other herbicides to control barnyardgrass and its effects on photosynthetic parameters of the plant. However, there are few studies in the literature dealing with the effect of utilization of saflufenacil on the photosynthetic parameters of barnyardgrass resistant and susceptible to herbicides when applied as a mixture. Therefore, the objectives of this study were to examine the interaction of tank-mixed herbicides with saflufenacil in the control of barnyardgrass and determine its effect on the photosynthesis and chlorophyll fluorescence parameters.

\section{MATERIALS AND METHODS}

The experiment was conducted in a greenhouse in the University of Santa Maria, Rio Grande do Sul, Brazil, during the 2017/18 growing season. The experimental units comprised 500-ml plastic pots containing soil. The treatments were arranged in a $2 \times 8$ factorial design with four replications. Factor A tested the resistant and susceptible to ALS-inhibiting herbicides barnyardgrass biotypes; factor B consisted of different herbicides treatments, namely saflufenacil (70 g a.i. ha $\left.{ }^{-1}\right)$, clomazone (180 g a.i. ha $\left.{ }^{-1}\right)$, imazapyr+imazapic $\left(73.5+24.5\right.$ g a.i. ha $\left.{ }^{-1}\right)$, cyhalofop-butyl (360 g a.i. ha $\left.a^{-1}\right), a$ combination of these herbicides with saflufenacil, and the control (untreated).

The seeds were sown in polyethylene trays and placed in a BOD-type germination chamber during a photoperiod time of 12/12 hours (day/night) at a temperature of $25^{\circ} \mathrm{C}$. When the plants exhibited the first expanded true leaves, four seedlings were transplanted to each experimental unit. The herbicides treatments were applied when the plants had 3 to 4 leaves, using a $\mathrm{CO}_{2}$-pressurized backpack sprayer with AI 110.015 fan-type spraying nozzles, set to provide an application volume of $150 \mathrm{~L} \mathrm{ha}^{-1}$. At the time of application, the temperature was $26^{\circ} \mathrm{C}$, relative humidity was $80 \%$, and the flooding began one day after application of the treatments.

The analyzed variables were barnyardgrass control 7, 14, 21 and 28 days after application of treatments (DAA), shoots dry matter (SDM) on 28 DAA and the interaction of the combined herbicides to these variables. Photosynthetic parameters and chlorophyll fluorescence emission were analyzed after 24 and 48 hours, respectively, of application of the treatments.

The control variable was performed by assigning percent scores in a $0-100 \%$ scale, where score zero corresponded to absent injuries, and score 100 to plants death. Dry matter of barnyardgrass shoots was collected 28 DAA and dried in aircirculation oven at $60{ }^{\circ} \mathrm{C}$ to constant biomass weight and adjusted to mass per plant ( $\left.\mathrm{g} \mathrm{plant}^{-1}\right)$.

Analysis of the results of the tank-mixed herbicides was carried out following the method proposed by COLBY (1967), where the effects of these interactions (synergistic, antagonistic or additive) were determined. Result of the interactions was obtained by the following equation: 
$\mathrm{E}=100-\{[(100-\mathrm{X}) \times(100-\mathrm{Y})] / 100\}$

where $\mathrm{E}$ is the expected value of the combined herbicides rates used, and $\mathrm{X}$ and $\mathrm{Y}$ correspond to the value reported for the herbicides applied alone. According to the results of this equation, when the value reported was higher than the expected one, the interaction is synergistic; when it is lower, it is antagonistic; and, when is the same, it is additive. The observed and expected values were verified by the t-test $(\mathrm{P} \leq 0.05)$.

The photosynthetic parameters of barnyardgrass were assessed based on the criterion of the middle third of the last fully-expanded leaf at the stem, using a portable measurer Infra RedGasAnalyzer (IRGA), trademark LI-COR, model LI-6400 XT, and utilizing a photosynthetic radiation of $1500 \mu \mathrm{mol} \mathrm{m} \mathrm{m}^{-2} \mathrm{~s}^{-1}$ and $\mathrm{CO}_{2}$ concentration of 400

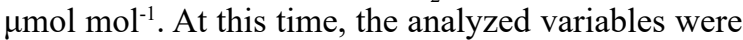
the net $\mathrm{CO}_{2}$ assimilation rate $\left(\mathrm{A}-\mu \mathrm{mol} \mathrm{CO}_{2} \mathrm{~m}^{-2} \mathrm{~s}^{-1}\right)$, stomatal conductance of water vapors $\left(\mathrm{Gs}-\mathrm{mol} \mathrm{H}_{2} \mathrm{O}\right.$ $\left.\mathrm{m}^{-2} \mathrm{~s}^{-1}\right)$, intracelullar concentration of $\mathrm{CO}_{2}(\mathrm{Ci}-\mu \mathrm{mol}$ $\mathrm{CO}_{2}$ mol air $\left.{ }^{-1}\right)$, transpiration rate $\left(\mathrm{E}-\mathrm{mol} \mathrm{H}_{2} \mathrm{O} \mathrm{m}{ }^{-2}\right.$ $\mathrm{s}^{-1}$ ), water use efficiency (WUE - $\mathrm{mol} \mathrm{CO}_{2} \mathrm{~mol} \mathrm{H}_{2} \mathrm{O}^{-}$ $\left.{ }^{1}\right)$ obtained by the ratio of the amount of $\mathrm{CO}_{2}$ fixed by photosynthesis to the transpired water, and carboxylation efficiency of the Rubisco (A/Ci) obtained by the ratio of the amount of $\mathrm{CO}_{2}$ fixed by photosynthesis to the $\mathrm{CO}_{2}$ internal concentration.

The chlorophyll $a$ fluorescence emission was analyzed at the leaves using a portable modulated chlorophyll fluorometer (Junior-Pam Chlorophyll Fluorometer Walz, Germany). The first fullyexpanded leaf was used for this measurement, which was carried out in the morning of a sunny day, and the leaf was previously adapted to dark for a period of half an hour (SOUZA et al., 2013). After this procedure, the initial fluorescence $\left(\mathrm{F}_{0}\right)$, maximum quantum efficiency of photosystem II (PSII) ( $\mathrm{F}_{\mathrm{v}} /$ $\left.\mathrm{F}_{\mathrm{m}}\right)$ and the electron transport rate $\left(\mathrm{ETR}_{\mathrm{m}}\right) \mathrm{F}_{\mathrm{v}} / \mathrm{F}_{\mathrm{m}}$ was obtained by the ratio of the fluorescence variable $\left(\mathrm{F}_{\mathrm{v}}=\right.$ $\left.\mathrm{F}_{\mathrm{m}}-\mathrm{F}_{\mathrm{o}}\right)$ to the maximum fluorescence $\left(\mathrm{F}_{\mathrm{m}}\right)$.

The data obtained were subjected to analysis of variance $(\mathrm{P} \leq 0.05)$, and when variance was significant, treatments mean values were grouped and analyzed by the Scott-Knott's test $(\mathrm{P} \leq 0.05)$.

\section{RESULTS AND DISCUSSION}

Results of the analysis of variance showed statistical significance of the treatments for the variables analyzed. Barnyardgrass control with application of cyhalofop alone and mixed with saflufenacil showed a satisfactory result for both biotypes from 14 DAA and, in general, higher than $90 \%$ at 28 DAA, different from the other treatments. Likewise, SDM was lower than the other treatments (Table 1 and 2). Application of cyhalofop controlled barnyardgrass $(>90 \%)$ when the plants were at early stages ( 2 to 4 leaves), but at final growth stages it is less effective (KALSING et al., 2017). This herbicide and profoxydim, clethodim, propanil and glyphosate appear to be effective options for the control of barnyardgrass biotypes resistant to ALS-inhibiting herbicides and quinclorac (BONOW et al., 2018).

There was no difference between the applications alone or in a mixture of clomazone with saflufenacil however, these treatments did not show satisfactory control of both barnyardgrass biotypes (Table 1). The isolated application of saflufenacil did not differ of the untreated from the control for the resistant biotype (Table 1). This result was consistent with a study in which barnyardgrass control with single application of $50 \mathrm{~g}$ a.i. saflufenacil was not effective (JHALA et al., 2013), requiring complementation to achieve an effective control of plants of the Poaceae family. Thus, tank-mixing herbicides with different mechanisms of action was important for a more effective control of resistant weed plants (BONOW et al., 2018).

The variables control and SDM did not exhibit difference between the untreated experiment (control) and that with imazapyr+imazapic for the resistant biotype, but for the susceptible biotype, control at all assessment times was higher, and SDM was lower compared to the herbicide-untreated experiment (Table 2). In the comparison of both biotypes, SDM was higher for the resistant biotype (Table 2), confirming its resistance to imidazolines.

Barnyardgrass control with a single cyhalofop application or tank-mixed with saflufenacil exhibited a difference 7 DAA, when the combined herbicides indicated control above $90 \%$ and the treatment with a single herbicide indicated control of approximately $70 \%$ (Table 1 ). The interaction between cyhalofop and saflufenacil was synergistic until 14 DAA, and was additive in the subsequent assessments for the resistant biotype (Table 3). Thus, saflufenacil can be an alternative for increasing the control spectrum in rice crops when mixed with cyhalofop, given that it did not affect the efficiency of barnyardgrass resistant to ALS-inhibiting herbicides in this study. Saflufenacil mixed with sethoxydim provides effective control of barnyardgrass, with no antagonistic effect compared to the application of sethoxydim alone (JHALA et al., 2013). The saflufenacil + clomazone treatment was synergistic 
Table 1 - Control (\%) of resistant (R) and susceptible (S) barnyardgrass biotypes 7, 14, 21 and 28 days after application (DAA) of different herbicides applied alone and tank- mixed.

\begin{tabular}{|c|c|c|c|c|c|c|c|c|}
\hline \multirow[t]{2}{*}{ Treatment } & \multicolumn{2}{|c|}{----------7DAA--------- } & \multicolumn{2}{|c|}{----------14DAA--------- } & \multicolumn{2}{|c|}{---------21DAA--------- } & \multicolumn{2}{|c|}{-------28DAA-------. } \\
\hline & $\mathrm{R}$ & $\mathrm{S}$ & $\mathrm{R}$ & $\mathrm{S}$ & $\mathrm{R}$ & S & $\mathrm{R}$ & $\mathrm{S}$ \\
\hline Control & $0 \mathrm{eA}^{1}$ & $0 \mathrm{dA}$ & $0 \mathrm{dA}$ & $0 \mathrm{dA}$ & $0 \mathrm{cA}$ & $0 \mathrm{dA}$ & $0 \mathrm{cA}$ & $0 \mathrm{cA}$ \\
\hline Saflufenacil & $28 \mathrm{~dB}$ & $79 \mathrm{bA}$ & $4 \mathrm{~dB}$ & $84 \mathrm{aA}$ & $4 \mathrm{cB}$ & $53 \mathrm{cA}$ & $0 \mathrm{cB}$ & $34 \mathrm{bA}$ \\
\hline Clomazone & $31 \mathrm{dA}$ & $36 \mathrm{cA}$ & $48 \mathrm{bA}$ & $54 \mathrm{cA}$ & $40 \mathrm{bA}$ & $44 \mathrm{cA}$ & $22 \mathrm{bA}$ & $24 \mathrm{bA}$ \\
\hline Imazapyr+imazapic & $1 \mathrm{eA}$ & $98 \mathrm{aA}$ & $1 \mathrm{~dB}$ & $100 \mathrm{aA}$ & $1 \mathrm{cB}$ & $100 \mathrm{aA}$ & $0 \mathrm{cB}$ & $100 \mathrm{aA}$ \\
\hline Cyhalofop & $70 \mathrm{bA}$ & $72 \mathrm{bA}$ & $89 \mathrm{aA}$ & $91 \mathrm{aA}$ & $87 \mathrm{aA}$ & $90 \mathrm{aA}$ & $97 \mathrm{aA}$ & $94 \mathrm{aA}$ \\
\hline $\begin{array}{l}\text { Saflufenacil + } \\
\text { Clomazone }\end{array}$ & $58 \mathrm{cB}$ & $83 \mathrm{bA}$ & $52 \mathrm{bB}$ & $76 \mathrm{bA}$ & $37 \mathrm{bB}$ & $62 \mathrm{bA}$ & $29 \mathrm{bA}$ & $47 \mathrm{bA}$ \\
\hline $\begin{array}{l}\text { Saflufenacil + } \\
\text { Imazapyr+imazapic }\end{array}$ & $32 \mathrm{~dB}$ & $78 \mathrm{bA}$ & $19 \mathrm{cB}$ & $91 \mathrm{aA}$ & $12 \mathrm{cB}$ & $91 \mathrm{aA}$ & $3 \mathrm{cB}$ & $93 \mathrm{aA}$ \\
\hline $\begin{array}{l}\text { Saflufenacil + } \\
\text { Cyhalofop }\end{array}$ & $91 \mathrm{aA}$ & $96 \mathrm{aA}$ & $97 \mathrm{aA}$ & $97 \mathrm{aA}$ & $97 \mathrm{aA}$ & $100 \mathrm{aA}$ & $99 \mathrm{aA}$ & $100 \mathrm{aA}$ \\
\hline CV. $(\%)^{2}$ & \multicolumn{2}{|c|}{----------12.09--------- } & \multicolumn{2}{|c|}{------------14.83----------- } & \multicolumn{2}{|c|}{-----------31.82--------- } & \multicolumn{2}{|c|}{------------34.09-------- } \\
\hline
\end{tabular}

Legend: ${ }^{1}$ Means followed by equal uppercase letters in rows, comparing biotypes for each period of assessment, and lowercase letters in column, comparing herbicides for each biotype, did not indicate significant difference according to the Scott-Knott's test $(\mathrm{P} \leq 0.05)$. ${ }^{2}$ Coefficient of Variation.

7 DAA for the resistant biotype (Table 3). The synergism shown 7 DAA can be explained by the function of potentializing the oxidative stress caused by saflufenacil (DALAZEN et al., 2015), causing severe injuries to the plants.

Saflufenacil and imazapyr+imazapic interaction at 7 DAA was antagonistic for the susceptible biotype, being the only comparison with this effect for the treatments tested (Table 3). Such reduced control, when comparing the expected with the observed one, is related to the contact damage caused by saflufenacil to the leaves, resulting in a difficulty of absorption of other herbicides to the leaves (CAMARGO et al., 2011). In a study carried out with a tank-mix of saflufenacil and

Table 2 - Shoots dry matter (SDM) (g/plant) of resistant (R) and susceptible (S) barnyardgrass 28 days after application (DAA) of different herbicides applied alone and tank-mixed.

\begin{tabular}{lcc}
\hline Treatment & $\mathrm{R}$ & $\mathrm{S}$ \\
\hline Control & $0.65 \mathrm{aA}$ & $0.88 \mathrm{aA}$ \\
Saflufenacil & $0.56 \mathrm{aA}$ & $0.47 \mathrm{bB}$ \\
Clomazone & $0.29 \mathrm{bA}$ & $0.13 \mathrm{cA}$ \\
\hline Imazapyr+imazapic & $0.58 \mathrm{aA}$ & $0.01 \mathrm{~dB}$ \\
Cyhalofop & $0.03 \mathrm{cA}$ & $0.06 \mathrm{dA}$ \\
Saflufenacil + & $0.29 \mathrm{bA}$ & $0.18 \mathrm{cA}$ \\
Clomazone & $0.39 \mathrm{bA}$ & $0.26 \mathrm{cA}$ \\
\hline Saflufenacil + Imazapyr+imazapic & $0.02 \mathrm{cA}$ & $0.01 \mathrm{dA}$ \\
Saflufenacil + & & \\
Cyhalofop & -------------------- \\
\hline CV.(\%)
\end{tabular}

Legend: ${ }^{1}$ Means followed by equal uppercase letters in rows, comparing biotypes for each period of assessment, and lowercase letters in column, comparing herbicides for each biotype, do not indicate significant difference according to the Scott-Knott's test ( $\mathrm{P} \leq 0.05)$. ${ }^{2}$ Coefficient of Variation. 
Table 3 - Observed (Obs) and expected (Exp) control (\%) of resistant (R) and susceptible (S) barnyardgrass in saflufenacil tank-mixed with different herbicides and the result of interaction (Int) 7, 14, 21 and 28 DAA of treatments.

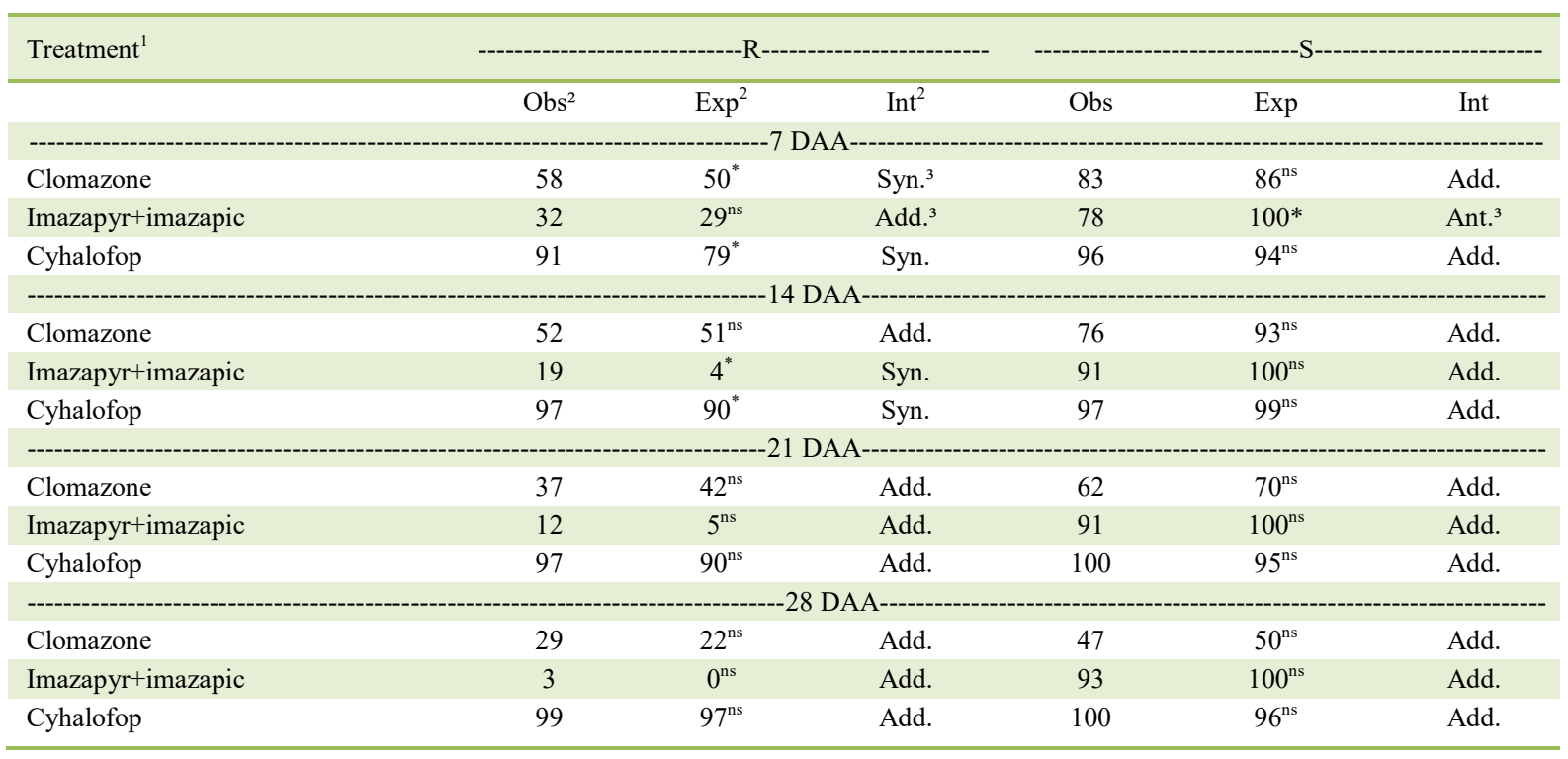

Legend: ${ }^{1}$ Tank-mix of saflufenacil with other herbicides. ${ }^{2} \mathrm{Obs}$, Exp and Int mean the values found in the experiment, the expected values determined by the Colby method, and the result of interaction based on the expected values, respectively. ${ }^{3}$ Ant. represents the result of interaction between the antagonistic herbicides, Add. means additive interaction, and Syn. indicates synergistic interaction. ${ }^{*}$ and ns indicate significant difference or no difference between the expected and actual values by the $t$ test $(\mathrm{P} \leq 0.05)$.

imazetaphyr, it was reported an efficacy of barnyardgrass, Sesbania herbacea, and Amaranthus palmeri control in CL-rice (MONTGOMERY et al., 2015). But it should be noted that this mixture of herbicides did not provide a better control of the barnyardgrass resistant biotype (Table 1 and 2), and so other herbicides should be included in the chemical control of this biotype.

The treatment with imazapyr+imazapic alone and tank mixed with saflufenacil exhibited higher net $\mathrm{CO}_{2}$ assimilation rate (A), WUE and instantaneous carboxylation efficiency of Rubisco $(\mathrm{A} / \mathrm{Ci})$ for the resistant biotype (Figure 1). The lesser effect of this herbicide to the resistant biotype was expected due to resistance to ALS-inhibiting herbicides characteristic. The susceptible biotype, in general, exhibited reduced stomatal conductance (Gs) compared to the control due to the application of different herbicides, but the treatment with cyhalofop did not differ from the control (Figure 1).

The Gs indicated stomatal closure, and adjustment of this parameter was vital to prevent water loss and for $\mathrm{CO}_{2}$ penetration (TAIZ \& ZEIGER, 2009). Stomatal closure in response to herbicides application may be due to the fact that they act in diverse plant physiological processes, causing the generation of chemical signals, resulting in the stomatal closure and, thereby, reducing the $\mathrm{CO}_{2}$ intake for the photosynthetic process. In addition, in general there was variation in response do both biotypes to cyhalofop, saflufenacil and clomazone herbicides for evaluated variables (Figure 1). These differences can be related to the genetic variability of the specie (ALTOP el al. 2018). Barnyardgrass biotypes can show high natural genetic variability and thus show a difference in susceptibility to the studied herbicides (LE et al., 2017; NGUYEN et al., 2020), reflecting on photosynthetic differences observed.

Variables $\mathrm{A}, \mathrm{WUE}$ and $\mathrm{A} / \mathrm{Ci}$ were more affected for the susceptible biotype when saflufenacil was applied alone, differing from the other treatments (Figure 1). This occurred because saflufenacil inhibits the PROTOX, blocking the biosynthesis route of clorophylls and heme groups and causing formation of oxygen reactive species in the cytosol, followed by oxidative stress in the membranes and leakage of cell content (DALAZEN et al., 2015). Thus, the damages caused by lipid peroxidation and reduction of cholorophyll biosynthesis in the leaves may account for the direct damage to the photosynthesis observed. 


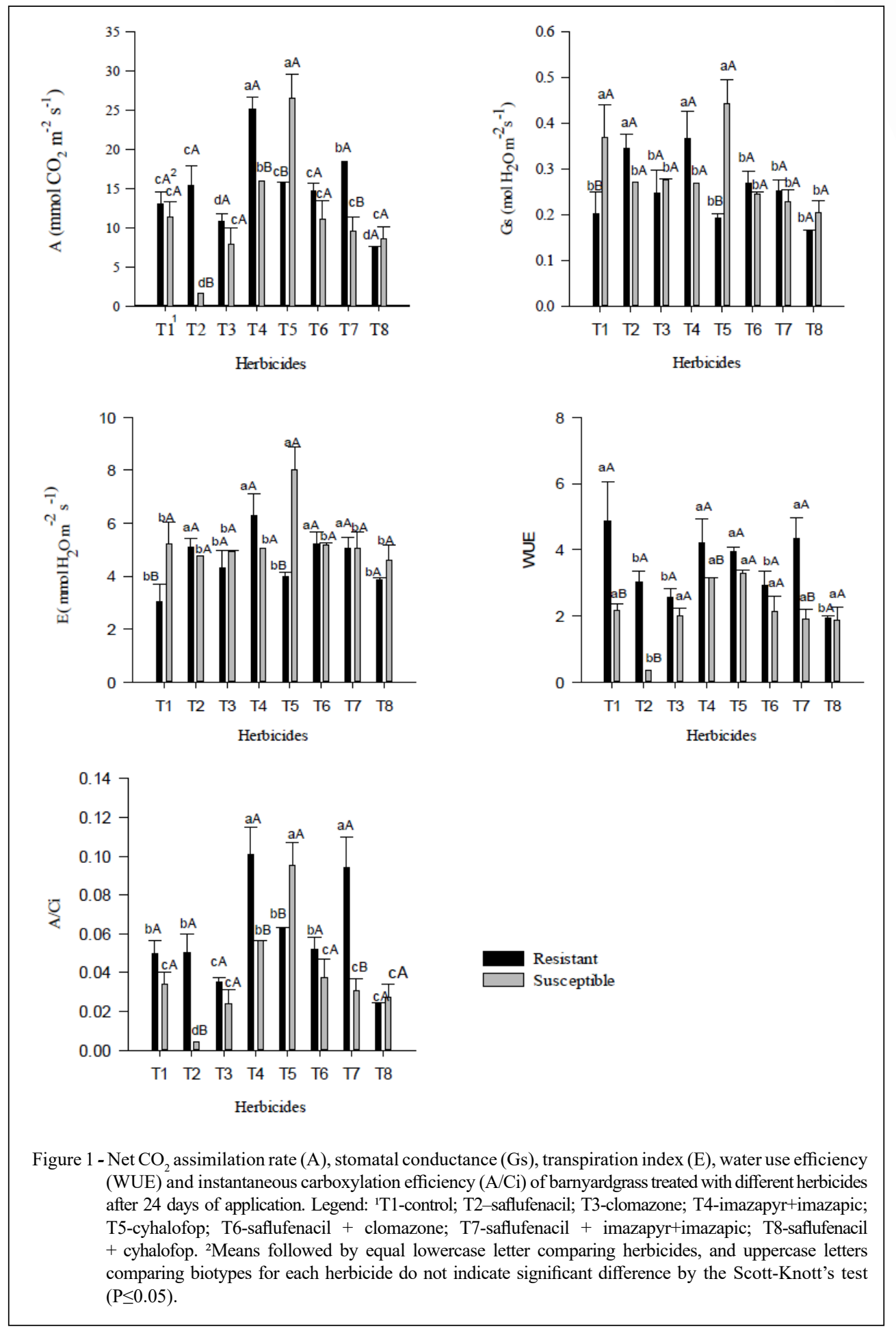

The treatments consisting of application of imazapyr+imazapic alone or mixed with saflufenacil, cyhalofop alone, and untreated control exhibited higher WUE for the resistant biotype, differing from other treatments (Figure 1). Likewise, the resistant biotype indicated higher WUE than the susceptible biotype in the above cited treatments, but for the cyhalofop treatment there was no statistical 
difference between both biotypes (Figure 1). The photosynthetic response of the resistant biotype to the imazapyr+imazapic herbicide was due to the resistance characteristic, thus causing no damage to the plant metabolism after application of these herbicides, reflecting on the maintenance of vital functions.
Treatment with imazapyr+imazapic alone resulted in higher maximum quantum efficiency $(\mathrm{Fv} / \mathrm{Fm})$ of PSII, electrons transport rate (ETRm) and non photochemical quenching (NPQ) in both barnyardgrass biotypes, not differing from the control, with average $\mathrm{Fv} / \mathrm{Fm}$ ratio of 0.8

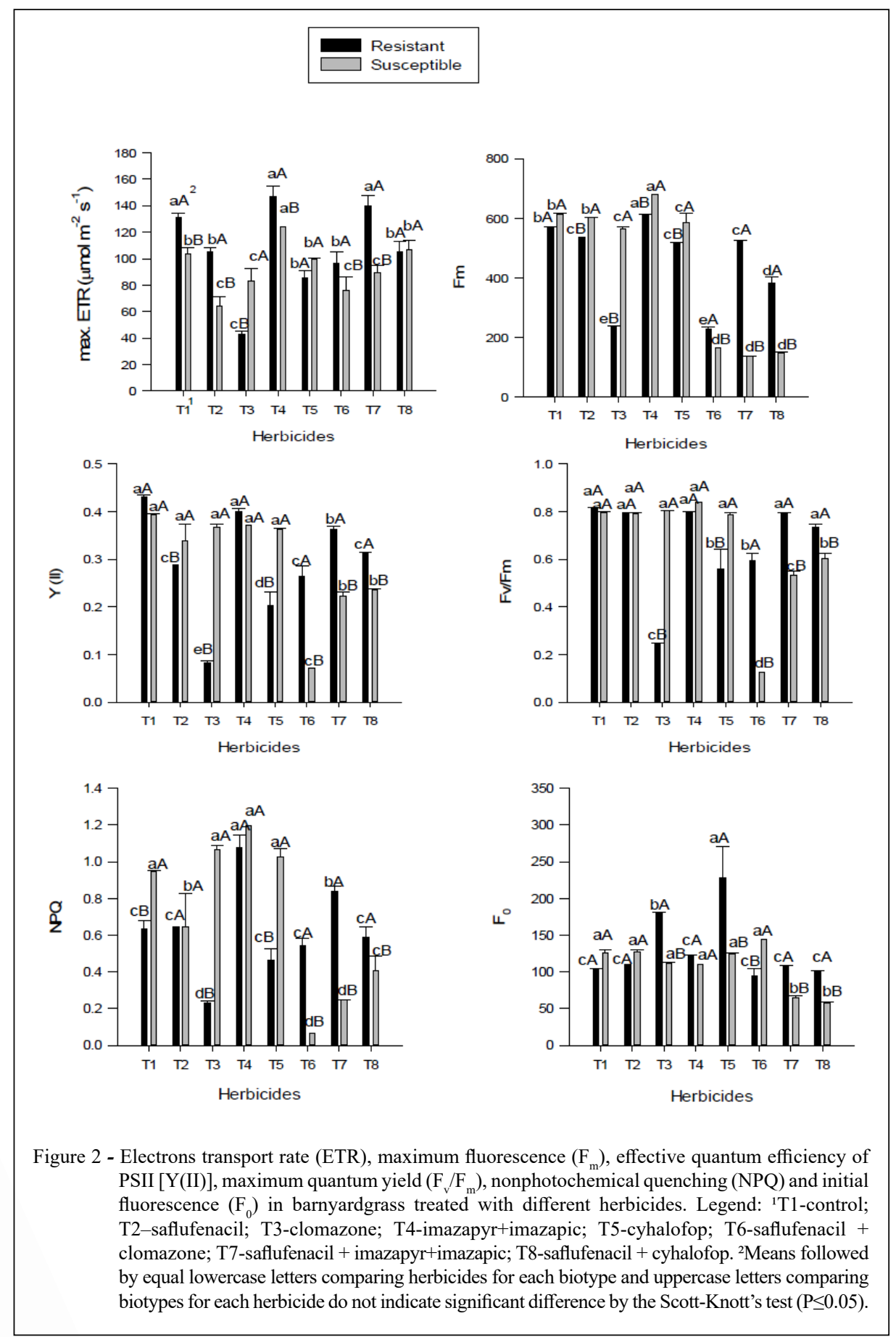

Ciência Rural, v.50, n.7, 2020. 
(Figure 2). These results are due to ALS-inhibitors resistance to the biotype. When a plant maintains its photosynthetic apparatus intact, Fv/Fm varies from 0.75 to 0.85 (BOLHÀR-NORDENKAMPF et al., 1989), and a decrease in this ratio reflected the presence of photoinhibitory damage in the PSII reaction centers. Increased NPQ reflected the steady state of the primary electron acceptor of PSII, the plastoquinone (PQ), providing an estimate of the PSII ability to utilize light energy to reduce NADP+, indispensable for photosynthetic carbon assimilation (MAXWELL \& JOHNSON, 2000). Similarly, the treatment with imazapyr+imazapic alone did not differ from the control for the variable quantum efficiency of PSII [Y(II)], and the ALS-inhibiting herbicides usually had a higher detoxification potential by the plants, which can diminish their effect on the fluorescence and photosynthesis processes (DALAZEN et al., 2016).

The chlorophyll fluorescence variables show no statistical difference for most of the variables when comparing the resistant and susceptible biotypes for the untreated (Figure 2). However, in some comparison were detected differences in response to herbicide treatment, attributed to herbicide resistance and genetic diversity (ALTOP el al. 2018). The use of saflufenacil mixed with herbicides differed in the two biotypes, with more effect on the chlorophyll fluorescence processes for the susceptible biotype (Figure 2). Clomazone was the herbicide that caused less photosynthetic efficiency for the resistant biotype, reducing ETR, Fv/FM, Y (II) and NPQ (Figure 2). The determining factor of this efficiency is the ability through which the electrons are removed from the PSII quinone receptor, which is directly related to the rate of ATP and NADPH consumption, products from the electrons photosynthetic transport (BAKER \& ROSENQVIST, 2004). This can be explained by the plant clomazone action as it acts indirectly in the photosynthesis process, inhibiting the enzyme responsible for the synthesis of basic carotenoid precursors and has the function of protection of chlorophyll against photooxidation.

\section{CONCLUSION}

The addition of saflufenacil in most combinations does not interfere with the response of the herbicides tested for susceptible and resistant barnyardgrass control, which is effective with application of cyhalofop. In general, application of saflufenacil and clomazone to barnyardgrass biotypes has negative effect to Gs, E, WUE and ETR parameters.

\section{ACKNOWLEDGEMENTS}

The authors want to thank the Fundo de Incentivo à Pesquisa (FIPE - UFSM) by the scientific initiation scholarship provided to the first author and was financed in part by the Coordenação de Aperfeiçoamento de Pessoal de Nível Superior (CAPES), Brasil - Finance code 001.

\section{DECLARATION OF CONFLICT OF INTERESTS}

The authors declare no conflict of interest. The founding sponsors had no role in the design of the study; in the collection, analyses, or interpretation of data; in the writing of the manuscript, and in the decision to publish the results.

\section{AUTHORS' CONTRIBUTIONS}

All authors contributed equally for the conception and writing of the manuscript.

\section{REFERENCES}

ALTOP, E. K. et al. Determination of morphological and genetic diversity of ALS (Acetolactate Synthase)-herbicide-resistant Echinochloa oryzoides biotypes in Rice. International Journal of Agriculture e Biology, v.20, n.3, p.628-636, 2018. Available from: $<$ https://www.cabdirect.org/cabdirect/abstract/20193099700>. Accessed: Jan. 8, 2020. doi: 10.17957/IJAB/15.0537.

BAKER, N. R.; ROSENQVIST, E. Applications of chlorophyll fluorescence can improve crop production strategies: an examination of future possibilities. Journal of Experimental Botany, v.55, n.403, p.1607-1621, 2004. Available from: <ncbi. nlm.nih.gov/pubmed/15258166>. Accessed: Jan. 11, 2019. doi: 10.1093/jxb/erh196.

BOLHÀR-NORDENKAMPF, H. R. et al. Chlorophyll fluorescence as probe of the photosynthetic competence of leaves in the field: a review of current instrument. Functional Ecology, v.3, p.497-514, 1989. Available from: $<$ https://www.jstor.org/stable/2389624? seq=1 $>$. Accessed: Jan. 11, 2019. doi: 10.2307/2389624.

BONOW, J. F. L. et al. Resistance of Echinochloa crusgalli var. mitis to imazapyr+imazapic herbicide and alternative control in irrigated rice. Planta Daninha, v.36, e018168627, 2018. Available from: $<$ http://www.scielo.br/scielo.php?script=sci_abstract\&pid=S0100$83582018000100228 \& \operatorname{lng}=$ en $\&$ nrm $=$ iso\&tlng $=$ pt $>$. Accessed: Jan. 11, 2019. doi: 10.1590/S0100-83582018360100028.

CAMARGO, E. R. et al. Rice Tolerance to saflufenacil in clomazone weed control program. International Journal of Agronomy, v.2011, n.1, p.1-8, 2011. Available from: <https:// www.hindawi.com/journals/ija/2011/402461/>. Accessed: Jan. 11, 2019. doi: $10.1155 / 2011 / 402461$.

COLBY, S. R. Calculating synergistic and antagonistic responses of herbicide combinations. Weeds, v.15, n.1, p.20-22, 1967. Available from: <https://www.jstor.org/stable/4041058?seq=1>. Accessed: Jan, 11, 2019. doi: 10.2307/4041058.

CONAB. Série histórica do arroz. Available from: <www.conab. gov.br>. Accessed: Jan. 17, 2019. 
COSTA, A. C. R. et al . Action of rain on formulations of glyphosate mixed with saflufenacil for the control of Brachiaria decumbens. Arquivos do Instituto Biológico, v.84, p.1-8 e0172015, 2017. Available from: <http://www.scielo.br/scielo. php?script $=$ sci_arttext\&pid $=$ S $1808-16572017000100221>$. Accessed: Jan. 11, 2019. doi: 10.1590/1808-1657000172015.

DALAZEN, G. et al. Sinergismo na combinação de glifosato e saflufenacil para o controle de buva. Pesquisa Agropecuária Tropical, v.45, n.2, p.249-256, 2015. Available from: <http://www. scielo.br/pdf/pat/v45n2/1517-6398-pat-45-02-0249>. Accessed: Jan. 11, 2019. doi: 10.1590/1983-40632015v4533708.

DALAZEN, G. et al. Occurrence and importance of herbicide resistance caused by degradation enhancement for weed management. Revista Brasileira de Herbicidas, v.15, n.1, p.2638, 2016. Available from: $<$ http://www.rbherbicidas.com.br/index. php/rbh/article/view/426>. Accessed: Jan. 11, 2019. doi: 10.7824/ rbh.v15i1.426.

GALON, L. et al. Interference periods of weeds infesting maize crop. Journal of Agricultural Science. v.10, n.10, p.197-205, 2018. Available from: <http://www.ccsenet.org/journal/index.php/ jas/article/view/0/36814>. Accessed: Jan. 11, 2019. doi: 10.5539/ jas.v10n10p197.

GROSSMANN, K. et al. Saflufenacil (Kixor ${ }^{\mathrm{TM}}$ ): Biokinetic Properties and Mechanism of Selectivity of a New Protoporphyrinogen IX Oxidase Inhibiting Herbicide. Weed Science, v.59, n.1, p.290-298, 2011. Available from: <https:// bioone.org/journals/weed-science/volume-59/issue-3/WS-D10-00179.1/Saflufenacil-Kixor--Biokinetic-Properties-andMechanism-of-Selectivity-of/10.1614/WS-D-10-00179.1.full>. Accessed: Jun. 20, 2019. doi: 0.1614/WS-D-10-00179.1.

HEAP, I. M. International Survey of Herbicide Resistant Weeds. Available from: <http://www.weedscience.com>. Accessed: Feb. $10,2019$.

JHALA, A. et al. Herbicide tank mixtures for broad-spectrum weed control in Florida Citrus. Weed Technology, v.27, n.1, p.129-137, 2013. Available from: <https://www.jstor.org/stable/23358318>. Accessed: Jan. 11, 2019. doi: 10.1614/WT-D-12-00105.1.

KALSING, A. et al. Susceptibility of Echinochloa populations to cyhalofop-butyl in Southern region of Brazil and impact of the weed phenology on its efficacy of control. Ciência Rural, v.47, n.4, 2017. Available from: < http://www.scielo.br/scielo. php? script $=$ sci_arttext\&pid $=$ S0103-84782017000400153 $>$. Accessed: Jan. 11, 2019. doi: 10.1590/0103-8478cr20160839.

LE, D. et al. Genetic diversity and herbicide resistance of 15 Echinochloa crus-galli populations to quinclorac in Mekong Delta of Vietnam and Arkansas of United States. Journal of Plant Biotechnology, v.44, p.472-477, 2017. Available from: $<$ http://www.kspbtjpb.org/journal/view.html?doi=10.5010/ JPB.2017.44.4.472>. Accessed: Jan. 8, 2020. doi: 10.5010/ JPB.2017.44.4.472.

MAXWELL, K.; JOHNSON, G. N. Chlorophyll fluorescence - a practical guide. Journal of Experimental Botany, v.51, n.345, p.659-668, 2000. Available from: <https://academic.oup.com/ jxb/article/51/345/659/652534>. Accessed: Jan. 11, 2019. doi: $10.1093 /$ jexbot/51.345.659.

MONTGOMERY, G. B. et al. Utilization of saflufenacil in a Clearfield rice (Oryza sativa) system. Weed Technology, v.29, p.255-262, 2015. Available from: <https://www.jstor.org/ stable/43702334?seq=1>. Accessed: Jan. 17, 2019. doi: 10.1614/ WT-D-14-00091.1.

NGUYEN, H. T. et al. Genetic diversity of glyphosate resistant Echinochloa colona in Australia. Journal of Research in Weed Science, v.3, p.145-161, 2020. Available from: <http://www. jrweedsci.com/article_92486.html $>$. Accessed: Jan. 8, 2020. doi: 10.26655/JRWEEDSCI.2020.2.3.

SOUZA, T. C. et al. The influence of ABA on water relation, photosynthesis parameters, and chlorophyll fluorescence under drought conditions in two maize hybrids with contrasting drought resistance. Acta Physiologiae Plantarum, v.35, p.515527, 2013. Available from: <https://www.alice.cnptia.embrapa. br/handle/doc/939313>. Accessed: Jan. 11, 2019. doi: 10.1007/ s11738-012-1093-9.

TAIZ, L.; ZEIGER, E. Fisiologia vegetal. 4.ed. Porto Alegre: Artmed, p.819. 2009.

ZHANG, Z. et al. Effects of common Echinochloa varieties on grain yield and grain quality of rice. Field Crops Research, v.203, p.163-172. 2017. Available from: <https://www.sciencedirect. com/science/article/abs/pii/S037842901630675X?via\%3Dihub>. Accessed: Jan. 11, 2019. doi: 10.1016/j.fcr.2016.12.003. 